Nursing News: Jurnal Ilmiah Keperawatan Vol 5, No 3 Tahun 2021, hal 102-110

Tersedia online di https://publikasi.unitri.ac.id/index.php/fikes

ISSN 2527-9823(online)

\title{
Riwayat Penyakit Kardiovaskuler Dan Kejadian Happy Hypoxia Pada Pasien Suspek Covid-19
}

\author{
Wahyu Dini Metrikayanto ${ }^{1}$, Novita Dewi ${ }^{2}$, Rachmat Chusnul Choeron ${ }^{3}$ \\ ${ }^{1,2,3)}$ Fakultas Ilmu Kesehatan Universitas Tribhuwana Tunggadewi \\ Email:.wmetrik@yahoo.com
}

\begin{abstract}
Happy Hypoxia is one of the symptoms of Covid-19 that is often not known by society. This condition is often found in cases of Covid-19 with very low oxygen levels in the blood. Happy Hypoxia can be fatal with the failure of several organs of the body. The purpose of this study was to determine the relationship between the incidences of happy bypoxia in suspected Covid-19 patients with a bistory of cardiovascular disease at the ER Panti Waluya Hospital, Malang. The design of this study was cross sectional with a total sample of 18 Covid-19 patients selected using the Total Sampling technique. Data about Happy Hypoxia and history of cardiovascular disease were taken based on secondary data from Medical Records in the ER Panti Waluya Hospital, Malang. Based on the results of the Fisher Exact Test, it was found that $p=(0.0477)<(0.050)$ so H1 was rejected, meaning that there was no relationship between the incidence of happy bypoxia in suspected Covid-19 patients with a history of cardiovascular disease in the ER Panti Waluyo Hospital, Malang City. This means that the incidence of happy hypoxia in Covid-19 patients is not only related to cardiovascular disease
\end{abstract}

Keywords: cardiovascular desease, covid-19, happy bypoxia

\begin{abstract}
ABSTRAK
Salah satu gejala Covid-19 yang sering tidak diketahui oleh masyarakat umum adalah happy bypoxia. Kondisi ini sering ditemukan kasus Covid-19 dengan kadar oksigen dalam darah sangat rendah sehingga bisa berdampak pada terjadinya pingsan atau bisa berakibat fatal juga dengan adanya kekagalan beberapa organ organ tubuh. Tujuan dari penelitian ini adalah untuk mengetahui Hubungan Kejadian Happy Hypoxia Pada Pasien Suspek Covid-19 Dengan Riwayat Penyakit Cardiovaskuler Di UGD Rs Panti Waluya Malang. Desain penelitian ini menggunakan cross sectional dengan jumlah sampel sebanyak 18 pasien Covid-19 yang dipilih dengan tekhnik Total Sampling. Data tentang Happy Hypoxia dan riwayat penyakit kardiovaskuler diambil berdasarkan data sekunder dari Rekam Medik di UGD RS Panti Waluya Malang. Berdasarkan hasil uji Fisher Exact Test didapatkan $p=(0,477)>(0,050)$ sehingga $\mathrm{H}_{1}$ ditolak, artinya tidak ada Hubungan Kejadian Happy Hypoxia Pada Pasien Suspek Covid-19 Dengan Riwayat Penyakit Kardivaskuler Di UGD RS Panti waluyo Kota Malang.. Hal ini memberikan makna bahwa kejadian happy bypoxia pada pasien Covid19 tidak hanya berkaitan dengan penyakit kardiovaskuler.
\end{abstract}

Kata kunci: Covid-19, Happy bypoxia, Penyakit Kardiovaskuler

Cara mengutip: Metrikayanto WD, Dewi N, Choeron RC,. (2021). Hubungan Riwayat Penyakit Kardiovaskuler dengan kejadian Happy Hipoksia Pada Pasien Suspek Covid-19 di UGD. Nursing News: Jurnal Ilmiah Keperawatan. Vol 5, No 3, 2021 , hal 102-110. Retrieved from https://publikasi.unitri.ac.id/index.php/fikes/article/view/2301 


\section{PENDAHULUAN}

Coronavirus Disease atau COVID-19 diketahui mampu menyebar secara cepat dan luas ke seluruh penjuru dunia, termasuk wilayah Indonesia. Virus ini dapat menyebar melalui percikan (droplet) dari mulut atau hidung manusia dan kontak langsung dengan penderita. Ada beberapa faktor yang dapat menyebabkan seseorang lebih mudah terserang atau terpapar COVID-19, yaitu salah satunya ketika seseorang dengan imunitas yang rendah (Abdillah, 2020).

\section{$\begin{array}{lll}\text { Coronavirus } & 2019 \quad \text { (COVID-19) }\end{array}$}

mengakibatkan morbiditas dan mortalitas yang cukup besar di seluruh dunia sejak Desember 2019. Selain menimbulkan tanda gejala umum (demam, batuk, diare), namun juga menimbulkan penyakit parah yang dapat mengancam jiwa termasuk sindrom distress nafas akut (ARDS), gagal ginjal akut, miokarditis, dan kegagalan organ (Liu et al, 2020).

Salah satu gejala unik yang ditimbulkan dari COVID-19 adalah bappy bypoxia, dimana saturasi oksigen tubuh yang rendah, namun tubuh belum menunjukkan gejala dispnea. Data kejadian happy bypoxia di RS. Panti Waluya di dapatkan mulai tanggal 01-17 November 2020 didapatkan dari 40 pasien suspek Covid-19 diantaranya 28 pasien mengalami happy bypoxia.

Kondisi happy bypoxia jarang diketahui masyarakat umum. Sehingga berbahaya ketika deteksi terlambat. González-Duarte, \& Norcliffe-Kaufmann, (2020) mengungkapan bahwa pada pasien dengan bappy bypoxia bernapas dengan seperti biasanya namun akan menimbulkan ketidaknyamanan pasien sendiri. Serta dapat diketahui dengan melihat atau mengukur saturasi oksigen menggunkan oksimetri dimana akan ditemukan oksigen dalam darah yang konsentrasinya sangat rendah. Beberapa faktor menjelaskan bahwa oksigen kurang mengakibatkan dispnea pada pasien dengan COVID-19 namun kejadian Sp O 2 di bawah ini 80\%, kurva disosiasi oksigen, toleransi kadar oksigen rendah.

Happy bypoxia ini memungkinkan bahwa virus korona memiliki tindakan istimewa pada reseptor dalam menghambat suplai oksigen kedalam tubuh. Namun dalam hal ini tidak dapat ditemukan pada semua kasus COVID19 dengan masalah bappy bypoxia. Namun sering ditemukan kasus Covid-19 dengan kadar oksigen dalam darah sangat rendah sehingga bisa berdampak pada terjadinya pingsan atau bisa berakibat fatal juga dengan adanya kekagalan beberapa organ organ 
Nursing News: Jurnal Ilmiah Keperawatan Vol 5, No 3 Tahun 2021, hal 102-110

tubuh (Chaudhuri, Shanbhag, \& Nileshwar, 2020).

Berdasarkan hasil studi pendahuluan yang dilakukan pada UGD RS. Berdasarkan hasil studi pendahuluan pada tanggal 18 november 2020 dengan melakukan wawancara 5 orang keluarga pasien suspek COVID-19 di UGD RS Panti Waluya Malang, sebanyak 5 orang keluarga pasien tersebut tidak mengetahui apa itu happy hipoksia, tanda dan gejala, penganan awal, serta cara mendeteksi. Rendahnya pengetahuan keluarga pasien dengan kejadian bappy bypoxia disebabkan karena kurangnya informasi serta ketidaktahuan. Berdasarkan latar belakang tersebut diatas, peneliti tertarik untuk melakukan penelitian dengan judul "Hubungan Kejadian Happy Hypoxia Pada Pasien Suspek Covid-19 Dengan Riwayat Penyakit Kardiovaskuler Di UGD Rs Panti Waluya Malang”. Tujuan dari penelitian ini yaitu untuk mengetahui hubungan kejadian Happy Hypoxia pada pasien suspek Covid-19 dengan riwayat penyakit Kardiovaskuler di UGD RS Panti Waluya (RSPW) Malang.

\section{METODE PENELITIAN}

Penelitian ini menggunakan cross sectional design, dimana pengambilan data hanya dilakukan sekali saja untuk mengetahui hubungan riwayat penyakit kardiovaskuler dengan kejadian bappy bypoxia pada pasien supek covid-19 kardiovaskuler di UGD RS Panti Waluya Kota Malang.

Populasi pada penelitian miniriset ini yaitu seluruh pasien suspek covid-19 yang mengalami bypoxia pada tanggan 1-30 oktober 2020 sebanyak 18 pasien dengan kriteria inklusi; 1) pasien dengan suspek covid-19, 2) pasien mengalami hypoxia. Total sampling digunakan dalam penentuan sampel penelitian ini, sehingga jumlah sampel sebanyak 18 pasien. Penelitian ini dilakukan pada tanggal 1 sampai 30 Oktober 2020 di UGD RS Panti Waluya Malang. Terdapat 2 variabel yang diteliti pada penlitian ini yaitu; riwayat penyakit kardiovaskuler (variabel bebas) dan kejadian hipoksia (variabel tergantung). Untuk mengetahui atau mengukur variabel tersebut diatas, maka instrumen yang digunakan adalah lembar catatan yang digunakan untuk menyalin data sekunder dari Rekam Medik di UGD RS Panti Waluya Malang. Data penelitian yang diperoleh data sekunder rekam medis selanjutnya diolah melalui beberapa tahapan, yaitu; editing, scoring, coding, tabulating. Analisis data dilakukan berupa analisis univariat dan analisis bivariat. Analisis univariat dilakukan untuk mengidentifikasi masing-masing variabel (riwayat penyakit kardiovaskuler dan kejadian happy bypoxia). Selanjutnya analisis bivariat yang digunakan untuk mengetahui keeratan. 
Hubungan variabel independen (riwayat penyakit kardiovaskuler) dengan variabel dependen (kejadian bappy bypoxia) adalah uji statistik Fisher Exact Test. Hal ini untuk mengetahui hubungan antara variabel independen skala nominal dengan variabel dependen skala nominal.

Sikap ilmiah yang dipegang oleh peneliti dalam melaksanakan seluruh kegiatan prinsip etika penelitian. Etika penelitian yang diperhatikan antara lain; 1) Beneficience, 2) Confidentiality, 3) Justice, 4) Veracity.

\section{HASIL}

Karekateristik responden dalam penelitian ini meliputi Jenis kelamin, usia, Diagnosa Medis, Saturasi Oksigen dan riwayat penyakit kardiovaskuler.

Tabel 1 Distribusi Frekuensi Responden Berdasarkan Jenis Kelamin, Usia, Diagnosa Medis, Saturasi Oksigen Dan Riawayat Penyakit Kardiovaskuler Di UGD. RS Panti Waluyo Bulan Okteber Tahun 2020

\begin{tabular}{llcc}
\hline \multicolumn{1}{c}{ Variabel } & \multicolumn{1}{c}{ Kategori } & $\mathbf{F}$ & $\mathbf{( \% )}$ \\
\hline Jenis kelamin & Laki-laki & 11 & 61,1 \\
\cline { 2 - 4 } & Perempuan & 7 & 38,9 \\
\hline Usia & 1-20 Tahun & 2 & 11,1 \\
\cline { 2 - 4 } & 21-40 Tahun & 2 & 11,1 \\
\cline { 2 - 4 } & 41-60 Tahun & 8 & 44,4 \\
\cline { 2 - 4 } & 61-80 Tahun & 6 & 33,3 \\
\hline Diagnosa Medis & Suspek covid- & 18 & 100,0 \\
& 19 & & \\
\hline Total & & 18 & 100 \\
\hline
\end{tabular}

Berdasarkan tabel 1 menunjukan bahwa sebagian besar responden berjenis kelamin laki-laki (11 orang, 61,1\%), hampir setengahnya berusia 41-60 tahun (8 orang, 44,4\%), dan seluruhnya berdiagnosa medis suspek covid-19 (18 orang, 100\%).

Hasil penelitian Riwayat Penyakit Kardivaskuler pada pasien suspek covid-19 di UDG RS Panti Waluyo Kota Malang, data disajikan pada tabel berikut:

Tabel 2 Distribusi Frekuensi Riwayat Penyakit Kardivaskuler pada pasien suspek covid-19 di UDG RS Panti Waluyo Kota Malang Tahun 2020

\begin{tabular}{ccc}
\hline $\begin{array}{c}\text { Riawayat Penyakit } \\
\text { Kardiovaskuler }\end{array}$ & F & $\mathbf{\%}$ \\
\hline Ada & 8 & 44,4 \\
\hline Tidak Ada & 10 & 55,6 \\
\hline Total & 18 & 100,0 \\
\hline
\end{tabular}

Berdasarkan tabel 2 didapatkan sebagian besar responden (10 orang, 55,6\%), tidak memilki riwayat penyakit kardiovaskuler pada pasien suspek Covid-19 Di UGD RS Panti Waluyo Kota Malang.

Hasil penelitian Kejadian Happy Hypoxia Pada Pasien Suspek Covid-19 Di UGD RS Panti Waluyo Kota Malang Kota Malang, data disajikan pada tabel berikut. 
Nursing News: Jurnal Ilmiah Keperawatan Vol 5, No 3 Tahun 2021, hal 102-110

Tabel 3 Distribusi Frekuensi Kejadian Happy Hypoxia Pada Pasien Suspek Covid-19 Di UGD RS Panti waluyo Kota Malang Kota Malang Tahun 2020

\begin{tabular}{ccc}
\hline Happy Hypoxia & F & $\mathbf{\%}$ \\
\hline Tidak Terjadi & 2 & 11,1 \\
\hline Terjadi & 16 & 88,9 \\
\hline Total & 18 & 100 \\
\hline
\end{tabular}

Berdasarkan tabel 3 hampir seluruhnya (16 orang, 88,9\%), memiliki saturasi oksigen buruk pada pasien suspek Covid-19 Di UGD RS Panti waluyo Kota Malang.
Berdasarkan tabel 4 bahwa kejadian bappy bypoxia pada pasien suspek Covid-19 hampir seluruhnya memiliki saturasi oksigen buruk (16 orang, 88,9\%), dari 16 orang tersebut 8 orang $(44,4 \%)$ memilki riwayat penyakit kardiovaskuler dan 8 orang (44,4\%) lainnya tidak memilki riwayat penyakit kardiovaskuler. Berdasarkan hasil uji Fisher Exact Test didapatkan $p=(0,294)<(0,050)$ sehingga $\mathrm{H}_{1}$ ditolak, artinya tidak ada hubungan kejadian happy bypoxia pada pasien Suspek Covid-19 Dengan Riwayat Penyakit Kardivaskuler Di UGD RS Panti Waluyo Kota Malang.

\section{Hubungan Kejadian Happy Hipokxia Pada Pasien Suspek Covid-19 Dengan Riwayat Penyakit Kardivaskuler Di UGD RS Panti waluyo Kota Malang}

Tabel 4 Hubungan Kejadian Happy Hypoxia Pada Pasien Suspek Covid-19 Dengan Riwayat Penyakit Kardivaskuler Di UGD RS Panti waluyo Kota Malang Tahun 2020

\begin{tabular}{|c|c|c|c|c|c|}
\hline \multirow[b]{3}{*}{$\begin{array}{l}\text { Riwayat } \\
\text { penyakit }\end{array}$} & \multirow[b]{3}{*}{ ada } & \multicolumn{2}{|c|}{ Kejadian Happy Hypoxia } & \multirow{2}{*}{ Total } & \multirow[b]{2}{*}{$p$} \\
\hline & & terjadi & tidak terjadi & & \\
\hline & & 8 & 0 & 8 & \multirow{3}{*}{0.477} \\
\hline Kardiovaskuler & tidak ada & 8 & 2 & 10 & \\
\hline \multicolumn{2}{|l|}{ Total } & $\begin{array}{c}16 \\
16.0\end{array}$ & $\begin{array}{c}2 \\
2.0\end{array}$ & $\begin{array}{c}18 \\
18.0\end{array}$ & \\
\hline
\end{tabular}

\section{PEMBAHASAN}

Berdasarkan tabel 2 didapatkan sebagian besar (10 orang, 55,6\%), tidak memilki riwayat penyakit kardivaskuler namun hampir setengahnya (8 orang, 44,4\%) memiliki riwayat penyakit kardiovaskuler pada pasien Suspek
Covid-19 Di UGD RS Panti Waluyo Kota Malang. Diketahui responden yang mempunyai riwayat penyakit kardiovaskuler sebagian besar berjenis kelamin laki-laki, hampir setengahnya berusia 41-60. 
Martiningsih \& Haris (2019) mengungkapkan bahwa pada penyakit kardiovaskular terjadi gangguan pada gangguan fungsi jantung dan pembuluh darah. Gangguan ini berpengaruh terhadap proses penyuplaian oksigen ke suluruh tubuh, apabila organ ini mengalami masalah tentunya berdampak buruk salah satunya adalah dengan terjadinya happy hipokxia pada pasien supek covid-19. Adapun beberapa faktor yang mempengaruhi kejadian penyakit kardiovaskuler diantarnya usia dan jenis kelamin.

Faktor usia juga berpengaruh terhadap kejadin penyakit kardiovaskuler, American Heart Association (2014) mengungkapkan dengan bertambahnya usia, resiko penyakit jantung akan meningkat. Seperti yang diketahui bersama bahwa, semakin bertambahnya usia kinerja organ tubuh manusia juga menurun. Menurut supriyani (2008, semakin bertambahnya usia seseorang maka akan mengalami kemunduran pula pada organya, sehingga pada kelompok usia $>45$ tahun berpengaruh terhadap kejadian PJK.

Faktor jenis kelamin juga berpengaruh terhadap kejadin penyakit kardiovaskuler dimana jenis kelamin laki-laki lebih sering mengalami penyakit kardiovaskuler dibandingkan dengan perempuan. Selanjutnya, laki-laki yang lebih sering mengkonsumsi alkohol bisa mengakibatkan tekanan darah meningkat dan beresiko terkena penyakit jantung dan merokok dapat merusak jantung dan pembuluh darah, yang meningkatkan resiko kondisi jantung seperti aterosklerosis dan serangan jantung AHA (2014). Hal ini sesuai dengan penelitian yang dilakukan oleh Muhafilah \& Saputri (2018) membuktikan bahwa sebagian besar responden memiliki riwayat keluarga dengan PJK sebanyak 37 responden $(60,7 \%)$ dipengaruhi oleh jenis kelamin laki-laki dikarenakan lebih berpotenssi karena kebiasaan merokok sehingga berpotensi terkena penyakit kardiovaskuler. Dengan demikiian dapat diketahui bahwa riwayat penyakit kardiovaskuler labih sering dialami oleh lakilaki dan semakin bertambah usia juga berpengaruh terhdap kejadian penyakit kardiovaskuler.

Berdasarkan Tabel 2 menunjukkan bahwa hampir seluruhnya 16 responden $(88,9 \%)$, memiliki saturasi oksigen buruk atau mengalami happy hipokxia pada pasien suspek Covid-19 Di UGD RS Panti waluyo Kota Malang. Diketahui responden yang mengalami happy hipokxia dipengaruhi oleh 
Nursing News: Jurnal Ilmiah Keperawatan Vol 5, No 3 Tahun 2021, hal 102-110

sebagian besar berjenis kelamin laki-laki, hampir setengahnya berusia 41-60 dan hampir seluruhnya memiliki saturasi oksigen buruk. González-Duarte \& NorcliffeKaufmann (2020) mengungkapkan bahwa kejadian bappy bypoxia adalah keadaan di mana pasien Covid-19 mengalami kekurangan oksigen dalam darah, namun tidak merasakan sesak. Hal ini berpengaruh terhadp suplai oksigen yang masuk kedalam tubuh serta kebutuhan oksigen dalam tubuh yang tidak seimbang. Suplai oksigen yang berkurang akan berfdampak pada berbagi kerusakan organ dalam tubuh serta bisa berdampak fatal yakni kemaitian. Adapun beberapa Faktor yang mempengaruhi kejadian Happi hipokxia pada pasien suspek covid-19 yakni, usia dan saturasi oksigen.

Faktor usia berpengaruh terhadap kejadian happy hipokxia pada pasien suspek covid-19 dimana pada kasus kejadian happy hypoxia didaptakan hampir setengah responden berusia dewasa akhir atau 41-60 tahun hal ini membuktikan bahwa dimana semakin usia bertambah tua maka akan mengalami penurun berbagai penurunun fungsi organ serta penurunan daya tahan tubuh yang berdampak pada berbagai penyakit menyerang salah satunya covid-19 yang berdampak pada kejadian happy hipokxia. Hal ini sesuai dengan penelitian yang dilakukan oleh Supriyano (2008) membuktikan bahwa usia di atas atau lebih dari 45 berpotesi mengalami penyakita jantung sehingga akan berdampak pada suplai oksegen keseluh tubuh. Saturasi oksigen juga berpengaruh terhadap kejadian happy hapokxia dimana kejadian happy hipoksia memiliki saturasi oksigen dibawah normal yakni 95\%, namun terkadang pasien suspek covid-19 walaupun saturasi oksigennya dibawah 95\% namun tidak menunjukan kehajian atau tanda hipokxia. Hal ini sesuai dengan penelitian yang dilakukan oleh González-Duarte, \& Norcliffe-Kaufmann, (2020) mengungkapkan bahwa heppy hipoksia ada kasu covid-19 biasanya penderita bernapas dengan seperti biasanya namun akan menimbulkan ketidaknyamanan pasien sendiri. Berdasarkan hasil uji Fisher Exact Test didapatkan $\mathrm{p}=(0,477)>(0,050)$ sehingga H1 ditolak, artinya tidak ada hubungan kejadian happy hypoxia pada pasien Suspek Covid-19 dengan riwayat penyakit kardiovaskuler di UGD RS Panti Waluyo Kota Malang. Hal ini memberikan makna bahwa kejadian happy hypoxia pada pasien Covid-19 tidak hanya berkaitan dengan penyakit kardiovaskuler. 
Namun hal ini tidak sesuai dengan penelitian yang dilakukan oleh Willim, Ketaren, dan Supit (2020) mengungkapkan bahwa ketidakseimbangan kebutuhan dan suplai oksigen yang bisa memicu terjadinya infark miokard dapat dipicu oleh peningkatan kebutuhan oksigen akibat infeksi sistemik dan hipoksia karena infeksi COVID-19. Hal ini yang menjadi alasan mengapa riwayat penyakit kardiovaskuler memiliki resiko komplikasi yang lebih tinggi. Komplikasi yang dapat ditimbulkan antara lain; miokarditis, infark miokard akut (IMA), gagal jantung akut, tromboemboli, dan aritmia.

Penelitian lain yang dilakukan oleh Hasanah, dkk (2020) yang membuktikan bahwa penyakit kardiovaskuler juga berpengaruh terhadap kejadian bappy bypoxia pada pasien suspek covid-19, dimana organ ini berperan penting dalam menyuplai oksigen sehingga, sehingga salah satu faktor penyebab terjadinya happy hipokxia juga berdampak apabila mengalami masalah akan berdampak yang fatal, bahkan bisa mengakibatlan juga kegagalan pada organ tersebut.

\section{KESIMPULAN}

Riwayat penyakit kardiovaskuler tidak berhubungan dengan happy hipoxia pasien suspek covid-19 di UGD RS Panti Waluyo Kota Malang.

\section{REFERENSI}

Aisyah, I. (2014). Hubungan Penggunaan Obat Kardiovaskular Terhadap Terjadinya Xerostomia Pada Pasien Penyakit Jantung Koroner Di RSU Dr. Pirngadi Medan. [Skripsi]. Fakultas Kedokteran Gigi Universitas Sumatera Utara, Medan.

Abdillah, L. A. (2020). Stigma Terhadap Orang Positif COVID-19.

Andreas, M., Romansyah, M. A., \& Zuandra, R. A. (2020).Laporan Kasus Silent Hypoxemia pada Penderita COVID-19 dengan Komorbid Diabetes Melitus. Medica Hospitalia: Journal of Clinical Medicine, 7(1A), 203-206.

American Heart Association. 2014. 2014 AHA/ACC Guideline for the Management of Patients With NonST-Elevation Acute Coronary Syndromes. Journal of the American College of Cardiology. 64 (24) : 139- 195.

American Heart Association. Cardiovascular Disease \& Diabetes. [http://www.heart.org]. 2015. Diakses dari:

http://www.heart.org/heartorg/conditi ons/more/diabetes/whydiabetesmatters $\angle$ cardiovascular-diseasediabetes ucm 313865 article.jsp\#.ws8 whihubiv

Chaudhuri, S., Shanbhag, V., \& Nileshwar, A. (2020). "Happy hypoxia" of COVID-19: Are we happy with our oxygen reserves?. Indian Journal of Respiratory Care, 9(2), 131

Dhont, S., Derom, E., Van Braeckel, E., Depuydt, P., \& Lambrecht, B. N. (2020).The pathophysiology of 'happy'hypoxemia in COVID19. Respiratory Research, 21(1), 1-9.

González-Duarte, A., \& Norcliffe-Kaufmann, L. (2020). Is' happy hypoxia'in COVID19 a disorder of autonomic interoception? A hypothesis. Clinical Autonomic Research, 30(4), 331-333.

Handayani , A., 2017, Sistem Konduksi Jantung, Buletin Farmatera, 2(3). 
Nursing News: Jurnal Ilmiah Keperawatan Vol 5, No 3 Tahun 2021, hal 102-110

http://jurnal.umsu.ac.id/index.php/bul etin farmatera/article/view/1197/1269

Hasanah, D. Y., Nauli, S. E., Putri, V. K. P., Arifianto, H., Suryana, N. M., Suryani, L. D., ... \& Probodewi, P. (2020). Cardiovascular Complications In COVID 19 Infection. Indonesian Journal of Cardiology, 41(2), 60-9.

Kementerian Kesehatan RI. (2014). Situasi kesehatan jantung. Retrieved from http://

www.depkes.go.id/article/view/150218 0000 3/situasi-kesehatan-jantung.html.

Martiningsih, M., \& Haris, A. (2019). Risiko Penyakit Kardiovaskuler pada Peserta Program Pengelolaan Penyakit Kronis (Prolanis) di Puskesmas Kota Bima: Korelasinya dengan Ankle Brachial Index dan Obesitas. Jurnal Keperawatan Indonesia, 22(3), 200-208.

Purnamasari, I., \& Raharyani, A. E. (2020). Tingkat Pengetahuan Dan Perilaku Masyarakat Kabupaten Wonosobo Tentang Covid-19.Jurnal Ilmiah Kesehatan, 10(1), 33-42.

Rilantono, L., 2015, Penyakit kardiovaskuler (PKV),FK UI, Jakarta.

Tobin, M. J., Laghi, F., \& Jubran, A. (2020). Why COVID-19 silent hypoxemia is baffling to physicians. American journal of respiratory and critical care medicine, 202(3), 356- 360.http://www.ncbi.nlm.nih.gov/pub med/32539537.

Scottish Intercollegiate Guidelines Network (SIGN). (2017). Risk estimation and the prevention of cardiovascular: Quick reference guide. Retrieved from https://www.sign.ac.uk/assets/qrg149. pdf

Trianifa, N. (2019). Klasifikasi penyakit jantung menggunakan metode support vector machine berdasarkan perbandingan algoritma pembacaan waktu dengan tekstur sinyal sebagai metode ekstraksi sinyal EKG (Doctoral dissertation, UIN Sunan Ampel Surabaya). http://digilib.uinsby.ac.id/38252/2/Nis a\%20Trianifa H02216011.pdf

Willyono, A., Presley, B., Kamallan, C., Primayani, D., Setiawan, E., Herawati, F., ... \& Irawati, L. (2018). Penyakit kardiovaskular: Seri pengobatan rasional. Yogyakarta: Graha Ilmu

Willim, H. A., Ketaren, I., \& Supit, A. I. (2020). Dampak Coronavirus Disease 2019 terhadap Sistem Kardiovaskular. $e$ CliniC, 8(2).

Liu, H., Chen, S., Liu, M., Nie, H., \& Lu, H. (2020). Comorbid Chronic Diseases are Strongly Correlated with Disease Severity among COVID-19 Patients: A Systematic Review and Meta-Analysis. Aging and disease, 11(3), 668-678. https://doi.org/10.14336/AD.2020.0502 